PART TWO

Development and Decolonization 



\section{4 \\ Living Well? The Battle for National Development}

THE COCHABAMBA SUMMIT

In April 2010, Bolivian President Evo Morales held an international conference on global climate change near Cochabamba, Bolivia. Representatives, indigenous groups, and social movements from 140 countries attended "The World Peoples' Summit on Climate Change and the Rights of Mother Earth" (also known as "the Cochabamba Summit"). Bolivia is already experiencing devastating effects of climate change. Its Amazonian regions have suffered terrible flooding over the past few years, while its desert lowlands have witnessed severe droughts. In the highlands, the two main glaciers that provide drinking water are shrinking. The Chacaltaya glacier disappeared completely in recent years; others have already lost 40-50 percent of their capacity (Democracy Now 2010a; Rosenthal 2009). Lake Poopó, near Oruro, has dried up completely. So it was with a great sense of urgency that Morales convened the Cochabamba Summit. In a festive air of popular democratic participation, some thirty thousand people and seventeen working groups met to negotiate resolutions intended to address the problems left unanswered by the 2009 United Nations Climate Change Conference, held in Copenhagen the previous December. In his opening address, President Morales set the tone for the meeting: "We are here because in Copenhagen, the so-called developed countries failed in their obligation to provide substantial commitments to reduce greenhouse gases. We have two paths: either Pachamama or death. Either capitalism lives or Mother Earth lives. Of course, brothers and sisters, we are here for life, for humanity, and for the rights of Mother Earth. Long live the rights of Mother Earth! Death to capitalism!" (Democracy Now 2010a). 
Morales had spent the previous year trying-unsuccessfully-to make these points. He began his crusade at the United Nations in September 2009, saying that he believed defending Mother Earth had become more important than defending human rights. He said that "Mother Earth, Planet Earth, can exist without human life, but human life cannot exist without Mother Earth" (Morales 2009). Then, at the Copenhagen Conference in December 2009, Morales called on world leaders to hold temperature increases over the next century to just one degree Celsius (instead of the two degrees Celsius finally agreed upon). Even more provocatively, he argued that rich countries should pay climate reparations-what he terms a "climate debt" - to those poorer countries suffering the effects of climate change. Warning of a "climate holocaust" that will destroy Africa and many island nations, he called for an international climate court of justice to prosecute countries for climate "crimes" (Vidal 2009).

The resulting "World Peoples Agreement" at the end of the Cochabamba Summit echoed Morales's concerns (Cooper 2010). It denounced the Copenhagen accords, and supported Morales's call to limit global warming to one degree Celsius. It also called for the passage of a Universal Declaration of the Rights of Mother Earth, the creation of an International Tribunal to prosecute polluters, protection for climate migrants, the establishment of an "Adaptation Fund" to help countries affected by climate change, and full recognition of the 2007 UN Declaration on the Rights of Indigenous Peoples, whose lands and livelihoods are most affected by climate change. The agreement concluded with the need to hold a global referendum to consult with the world's peoples on all of these issues, combining the fate of the planet with the need for global democracy.

\section{THE PACHAMAMA DISCOURSE: LOVING} MOTHER EARTH

The Cochabamba Summit cemented Morales's international reputation, giving him a highly visible platform for his long-standing criticism of imperialism, militarism, and neoliberalism. One of the most important accomplishments of the summit, he told Democracy Now's Amy Goodman, was that instead of just talking about the effects of climate change, this summit examined the underlying cause, namely, capitalism (Democracy Now 2010b). Morales has often spoken about the need to end irrational consumer-driven industrialization, saying that such forms of capitalism are the "worst enemy of humanity" (Democracy Now 2009). To this Western form of development, Morales posed a liberatory alternative: a sustainable model of development based on indigenous values and reverence for the pachamama, or Mother Earth, called vivir bien, to live well. In the first years of his administration, Morales often referred to vivir bien, arguing that the only way to end global warming is to end the "search for living better," or what he characterizes as the goal of 
consumerist capitalism. He explained it this way: "Living better is to exploit human beings. It's plundering natural resources. It's egoism and individualism. Therefore, in those promises of capitalism, there is no solidarity or complementarity. There's no reciprocity. . . . Living better is always at someone else's expense. Living better is at the expense of destroying the environment" (cited in Democracy Now 2009).

This discourse has been enormously influential, at least at the symbolic level. But while this discourse has increased Morales's reputation abroad, at home in Bolivia, there are ongoing and serious controversies over development. On the one hand, Morales and his government have vowed to put into place a sustainable development model based on indigenous values. On the other, the government continues to exploit its natural resources to bring in the income necessary to redistribute the benefits to Bolivia's poor populations. In this chapter, I demonstrate how these two seemingly irreconcilable impulses have been contested, and how they are articulated to the MAS state's notion of decolonization. I trace the ways in which the government has theorized indigeneity, vivir bien, and decolonization in its official documents, as well as its policies and practices, and show how the balance between them has changed over time. Development appears to be a malleable notion that can take on "indigenous" valences when necessary to support the overarching agenda of decolonization. Yet, ultimately, the Morales government has ignored radical alternatives based on indigenous values in favor of more traditional ideas of capitalist and extractivist development.

Focusing on the political economy of Bolivia under Morales draws our attention to a particular site of politics. In Rancière's terms, development decisions are a site of both politics and policing, just like the collective wedding described in chapter 3. As the description of the Cochabamba Alternative Climate Summit makes clear, Morales and the MAS government have represented natural resources and the environment as a site of emancipatory politics. Overturning the long history of exploitative relations between Bolivia as a producer of raw materials and foreign markets is not only a widely popular form of anti-imperialism, but also a form of decolonization, inasmuch as it benefits Bolivia's poor and indigenous populations. Yet this form of politics also enables a new form of policing, because the "indigenous" government consolidated power over decision-making about national development and natural resource extraction. I suggest that over time, the government decided its need to continue extractivist forms of development overshadowed other goals. In the process, decolonization lost much of its original emancipatory meaning, leaving indigenous activists with fewer resources to accomplish their political goals.

\section{THE 2006 NATIONAL DEVELOPMENT PLAN}

In the first years of Morales's administration, the MAS government made significant steps to transform the relation between the state and the market and 
overturn the neoliberal project of the previous decades. The MAS aimed to make the state a primary actor in the economy, re-embedding economic development in the fabric of social, political, and cultural life. This is an overt contestation of orthodox neoliberal ideology-but not practices-which urge the separation of the economic and the political. Orthodox neoliberal policies attempt to keep the state out of the economic sphere, protecting the freedom of individuals to make contracts in "free markets" (Harvey 2005). The government issued a road map to its plans in June 2006, when it published its Plan Nacional de Desarrollo (PND), or National Development Plan (Bolivia 2006). It is worth taking a close look at the language of the PND to understand both how the MAS discursively linked neoliberalism to colonialism and how it located its alternative project in indigenous customs and potential.

The PND describes the goal of national development as "remov[ing], from its roots, the profound social inequality and inhuman exclusion that oppress the majority of the Bolivian population, particularly those of indigenous origin" (1). This inequality, the PND makes clear, is the product of colonialism, capitalism, and neoliberalism. Colonialism, continuing through the republican period, denied indigenous peoples not only their dignity and their labor, but also their right to the means of production, especially land. Then, the capitalist primary export model of silver and tin mining deepened these inequalities, benefitting a small nucleus of oligarchs. Throughout the first half of the twentieth century, most of Bolivia's natural riches were exported to other countries, along with the profits from their exploitation. The reforms of the 1952 revolution, including nationalization of the mines, were not enough to overcome the original causes of the structural inequalities and social exclusions. Instead, the state capitalism of the second half of the twentieth century only gave rise to new regional oligarchs who appropriated state patrimony. This period ended in the crisis of external debt and hyperinflation, ushering in the neoliberal period (ibid).

The neoliberal model, says the PND, was imposed to resolve the failure of the welfare state, which was roundly held to be inefficient and corrupt. "In this way, the market took over the role of state, assigning resources for the production of goods and services, and also distributing wealth" (2). The result was the exacerbation of the concentration of wealth, access to means of production, and jobs to one-tenth of the population. This "inequality and social discrimination, called 'poverty' by neoliberal colonialism," led to compensatory measures such as the poverty reduction policies that often accompanied structural adjustment programs and, in 200o, the UN's Millennium Development Goals. Although this amounted to a recognition of the failure of the market and the need for state intervention, neoliberal anti-poverty efforts continued to be subject to the logic of the market. NGOs and foreign aid stepped into this void with development projects, but since they did not address the fundamental causes, they could not resolve the problems either, 
instead creating projects catering to foreign objectives, debilitating the government, and wasting enormous amounts of money. Thus, under neoliberalism, the PDN says, the development of the country was subject to the interests of multilateral organizations and transnational corporations (3).

This model of development failed because it is the product of a "system of ethnic, cultural, and political domination, impregnated with racism" (12). So the new development plan must have as its object

the suppression of the causes of the inequality and social exclusion in the country, which means to change to primary export model and the foundations of colonialism and neoliberalism that sustain it. That is to say, to dismantle not only the economic mechanisms, but also the political, cultural, colonial, neoliberal ones, erected by the dominant culture, which are encountered disseminated in the deepest interstices of the organization of the state and also in the minds of people across social and individual practices, to the detriment of solidarity and complementarity. (4)

To do this, the PND proposed an alternative model of development arising from social demands of the majority of the population whose voices were silenced by neoliberalism. Because neoliberalism conceived of development as exclusively associated with economic growth, delinked from the state or politics, "it expropriated from the people their right to propose and debate their common future" (9). Now, however, this population rejects the neoliberal development model, which was based on Western ideas and obscured mechanisms of domination and power. Instead the Plan offered a new model based on vivir bien, to live well-what Morales was referring to in his interview quoted above. Derived from the cosmovisión (worldview) of indigenous peoples, it refers to communitarian forms of convivencia, or living together. It implies intercultural respect and symmetries of power: "One cannot live well if others live badly" (10). The PND argues that this collective notion of well-being is very different from Western notions of individual well-being, which can be obtained at the expense of others or the environment. It also differs from Western notions in that it goes beyond the material and economic to include such values as emotions, recognition, difference, social prestige, and dignity (10). Bolivians are not alone in advancing this notion-in Ecuador, where it is called sumak kawsay (a Quechua term for "good life"), it is also promoted as the basis of alternative forms of development (see Radcliffe 2012).

The PND insisted that to put this alternative form of development into effect would require the intervention of the state as "promoter and protagonist of national development" (4). This is because the state is a "new power that surges from the popular and indigenous sectors, from the peasant communities, and from the workers of the city and the countryside"(14). It will act to transform society and the economy, but "only if all peoples and cultures are present in the economic and political decisions of the State" (15). This means that the people's 
capacity to decide must be recuperated within a new notion of the nation that recognizes the pluri-ethnicity and multiculturality of the country, as well as the vitality of the social movements. The PND suggested finally that these newly empowered social actors would create a new state during democratic debate in the Constituent Assembly. That did in fact happen (see chapter 2), and the language of vivir bien was a fundamental part of the constitution that emerged. Bolivia's 2009 Constitution reads: "The state is sustained in the values of unity, equality, inclusion, dignity, liberty, solidarity, reciprocity, respect, complementarity, harmony, transparency, equilibrium, equality of opportunity, social and gender equity in participation, common well-being, responsibility, social justice, distribution and redistribution of products and social goods, to live well" (Bolivia 2009, Art. 8, pt. 2; emphasis added).

The PDN sheds significant light on the ways the MAS state articulated indigeneity, development, and decolonization. This is evident in the way the document returns time and again to its assertion that the foundation of Bolivian society is its indigenous peoples, tying the well-being of all Bolivians and the nation as a whole to its indigenous peoples and social movements. By characterizing the majority of the population as indigenous, however, it elides the complex relationship between race and class that has led poor Bolivians to identify in some periods as campesinos (peasant farmers) and in others as indígenas or pueblos originarios (indigenous or original peoples) (Postero 2007a; Albó 2000; Canessa 2006). Many urban people have very ambiguous identities, adopting the category of cholo, taking pride in their indigenous heritage, but also identifying as members of the mestizo middle class (Barragán 2006; Rivera Cusicanqui 2010). We have already seen in the discussion about the collective wedding that the category of indigeneity is a site of ambiguity as well as of substantial symbolic and discursive work. Who counts as indigenous remains a central question in Bolivia today, and one that is susceptible to multiple and contested interpretations. Here we see how the authors of the PND utilized this ambiguity, combining values drawn from the indigenous repertoire with tried and true values of liberalism, then linking them to the internationally recognized discourses of multiculturalism, environmental sustainability, democratization, and human rights. The document demonstrates what a very rich repertoire indigenous culture and values can be, and how flexibly it can be adapted.

The PND articulates indigeneity to national development in a second, related way, by linking neoliberalism and colonialism as stages in a coherent long-term model of cultural and economic exploitation. The document explains that its authors reject the neoliberal definition of development as strictly economic or material, and intentionally redefine it to include cultural and political rights, especially focusing on human dignity and human rights. Thus, for these authors, development must be understood in terms of cultural values and forms of social organization (Bolivia 2006: 12). The MAS rhetoric challenging colonial neoliberalism 
articulates a reality that Bolivia's poor and indigenous people know all too well: the market is not a neutral site, but one that reinforces already existing power relations of race and class. That is, the MAS did not offer its project merely as a different economic model to be debated among dueling economists. Rather, it represented itself as creating a new decolonized nation based on social justice and multicultural equality. To use Rancière's terms, this is a form of politics, calling for the formerly invisible indigenous and poor peoples of Bolivia not only to be seen and heard but also to be the beneficiaries of national development.

\section{THE MORALES DEVELOPMENT PROJECT: REASSERTING THE ROLE OF THE CENTRAL STATE}

The most salient aspect of Morales's anti-neoliberal program had already begun as the PND was being developed. In May 2006, Morales "nationalized" the oil and gas sector, sending the Bolivian army to take over the foreign-owned natural gas installations in the eastern section of the country. Gas and mining resources were nationalized by the state after the 1952 revolution and run by state-owned companies until the neoliberal era, when they were privatized. As a result, there is a long collective memory of the state's involvement in exploitation of what is considered the national patrimony. Perhaps even more important, the mines constituted a large sector of public employment, with good salaries, benefits, and high status associated with working for the nation (Nash 1979). The miners' layoffs in the late 1980 s as part of the neoliberal restructuring were perceived by many as a blow to the dignity of Bolivia's working people (see Nash 1992). Thus Morales struck a deeply emotional and nationalist chord when he staged the takeover in May 2007.

Clearly, this reassertion of the role of the state in the economy defies the neoliberal model, signaling a reversal of the waves of privatizations of the 1990s. Yet it is not just a return to the past. Morales did not seize the assets of the foreign corporations working the gas concessions. Rather, the nationalization decree gave the companies six months to renegotiate their contracts with the state. It also sharply raised taxes and royalties on gas producers, and taxed natural gas profits, imposing what are called impuestos directos a los hidrocarburos (IDH). Previously, companies had retained some 82 percent of the profits, leaving the Bolivian state with only a small portion. The new taxes, royalties, and renegotiated contracts changed these proportions; under the new arrangement, the central government receives about 54 percent of the profits (Andean Information Network 2007a, b). However, this was hardly a "nationalization." By 2014, transnational corporations were producing 86 percent of exports, whereas Bolivia’s state-owned gas company YPFB only produces 14 percent (Arze 2016: 14). Thus, this model is neither an inward-turning policy like those practiced under so-called import-substitution industrialization in the 1970 s nor an end to the primary export model so decried 
in the PND. Bolivia's national development has remained deeply linked to global capitalism.

Vice President Álvaro García Linera explained this reliance on capitalist exploitation of hydrocarbons is part of the state's overall development model, which he calls "Andean-Amazonian capitalism":

It is a question of building a strong state, which can coordinate in a balanced way the three "economic-productive" platforms that coexist in Bolivia: the communitybased, the family-based and the "modern industrial." It is a question of transferring a part of the surplus of the nationalised hydrocarbons [oil and gas] in order to encourage the setting up of forms of self-organization, of self-management and of commercial development that is really Andean and Amazonian. Up to now, these traditional sectors have not been able to develop because of a "modern-industrial" sector that has cornered the surpluses. Our idea is that these traditional sectors should have an economic support, should have access to raw materials and markets, which could then generate prosperity within these artisan and family-based processes. Bolivia will still be capitalist in 50 or 100 years. (Stefanoni 2005)

According to García Linera, as the state invests in modernizing these indigenous family-based economies, over time a proletariat will emerge that is able to bring about the eventual transition to socialism.

In the meantime, however, as a result of this reassertion of control over profits from its natural resources, Bolivia was able to radically alter its financial situation. Government income from oil and gas went from U.S.\$173 million in 2002 to an estimated U.S.\$1.57 billion in 2007 (Bolivian Ministry of Hydrocarbons and Energy 2007, cited in Andean Information Network 2007a). Much of this was due to the fact that oil prices rose dramatically for the first years of the MAS administration, to nearly five times as much as during the Sánchez de Lozada years (Laserna Rojas et al. 2009: 31). The country's deficit, which averaged 4.9 percent during the neoliberal years, was effectively eliminated. For the first time, Bolivia began to run a surplus, which reached 5 percent of GDP in 2008, and it amassed large international reserves-almost $\$ 8.5$ billion (Weisbrot et al. 2009: 13, 20). Using this surplus in its fiscal policy, Bolivia was able to manage the financial downturn much better than other countries in the region. Moreover, the economy registered 5.2 percent annual growth from 2006 to 2009.

In recent years, the economy has faced some challenges. Most important, gas and mineral prices dropped, reducing revenue. U.S. trade sanctions imposed on Bolivia under the Andean Trade Promotion and Drug Eradication Act in 2007 prohibited Bolivian exports to the United States (Weisbrot et al. 2009: 27). And in December 2010, citing concerns that much of Bolivia's highly subsidized oil and gas was being sold on the black market in neighboring countries, Morales announced he was cutting fuel subsidies and raising domestic prices, classic neoliberal shock 
therapy. After massive demonstrations and strikes protesting what was called the gasolinazo, Morales backed down, urging social movements to come together with the government to come up with solutions (Quiroga 2011). This pointed out that Bolivia's challenge is to meet growing domestic demand while still being able to export to its neighbors, particularly Argentina and Brazil (Kaup 2010).

However, even during the global recession, Bolivia maintained its positive trajectory due to strong demand for its oil and gas from Brazil and Argentina. From 2006 to 2014, Gross Domestic Product reached an annual rate of 5 percent (INE, as reported in Arze 2016: 3). This dropped to about 4 percent in 2015, and slowed slightly in 2016 as commodity prices fell (Economist 2016). Nevertheless, the statistics for economic well-being have remained strong. Per capita income has risen from $\$ 1,010$ in 2005 to $\$ 2,922$ in 2013 . The country's exports went from $\$ 2.8$ billion in 2005 to $\$ 12.8$ billion in 2014 (ibid.). Urban unemployment fell from 8.1 percent in 2005 to 4 percent in 2013, and the government raised the minimum wage from 500 to 1,656 bolivianos a month (about \$236) in 2015. Probably most important is that the official levels of poverty have dropped considerably. Moderate poverty dropped from 60 percent in 2005 to 39 percent in 2013, while extreme poverty dropped from 38 percent to 18.8 percent in the same period (Arze 2016: 4).

The government claims that these increased levels of welfare are the result of the state's redistribution of money to the population. Like Venezuela, the Bolivian government began using state hydrocarbon resources for new forms of public spending, state subsidies, and social security programs. The 2005 oil and gas law established that the direct taxes from natural gas profits, the IDH, should be distributed to public universities, municipalities, departments (regional governments), and indigenous groups. Royalties are also distributed to the departments and state Treasury through a complicated formula (see Laserna et al. 2009). At the national level, the government has spent about 30 percent of its IDH monies on a popular retirement account for senior citizens, called the renta dignidad. (This is a continuation of the Bonosol program begun in the neoliberal years.) This is a universal program with no conditions: all Bolivians over the age of sixty now receive about $\$ 300$ a year. There are also two conditional cash transfer programs. This first is for children attending school, called the Juancito Pinto program, in which each child who attends school receives a small but significant amount (about $\$ 28$ per year) to encourage attendance and minimize dropouts (Yáñez et al. 2011). By 2010, the program was extended to cover all students from first to eighth grades-this means more than 1.7 million students receive the payment each school year (Navarro 2012; McGuire 2013). The second is the Juana Azurduy program for expectant and new mothers. The IDH also partially funds a $\$ 600$ million home construction program that provides loans to low-income families. Additionally, with Cuba's help, the central government funded a national literacy program in Spanish, Quechua, and Aymara; a "zero malnutrition" program to eliminate childhood malnutrition; 
and a large campaign for eye health, providing checkups and glasses for those who need them, as well as over 100,000 eye surgeries (Weisbrot and Sandoval 2007).

Some question the efficacy of these programs, since they do not raise the standard of living in a significant way (J. Webber 2011). Critics like the social movement leader Oscar Olivera suggest that cash transfers are merely neoliberal measures that act as simple palliatives, not changing the economic structure of the country in any substantial way (personal communication, August 2012; see also Arze 2016: 12). Some studies argue, however, that cash transfers are actually very important in bringing people out of poverty because they allow the poor to invest in the projects most likely to increase their production and income (Laserna et al. 2010; J. Goldstein 2013). This is a discussion that is occurring around the world, and cash transfers have become a regular part of many government policies. This is true, as James Ferguson (2015) points out, for many neoliberal countries. Ferguson argues that it is time to rethink these programs. He suggests that in many places, like South Africa, instead of thinking of cash transfers as gifts or social assistance based on generosity, many people consider them as part of social transfers, as rightful shares that are due to citizens who should benefit from the vast national wealth (2015:26). This is certainly the way the programs are characterized in Bolivia, and part of the reason why they are so popular.

It is very hard to assess the results of these programs, however. For instance, President Morales declared in a 2013 speech that the Juancito Pinto program had reduced the dropout rate from 6 percent in 2006 to 2 percent in 2012, but scholars point out there were no baseline studies beforehand (McGuire 2013: 15). Most studies to date show that CCT programs may provide short-term cash or increase enrollments, but do not affect long-term poverty rates (Avila 2012; McGuire 2013). In her analysis of the JP program, Alieza Durana concludes that the small amount of the transfers really do not cover the opportunity costs of attending school, the nutritional needs of the students, or other economic factors relating to attendance. Instead, the value of the program lies in "its symbolic value as a charisma-granting act" of President Morales, which reaffirms his "authority as a moral leader" (2010: 73). More study appears necessary, but for now we can say that the programs are enormously popular among Bolivia's poor and indigenous majority, Morales's main constituency.

Bolivia's economic model has been widely contested from both the Right and the Left. The conservative economist Roberto Laserna argued that the Morales government falls into the classic rentier mentality of previous governments, viewing hydrocarbon resources as something to be plundered without concern for making the country more productive or creating jobs (Laserna Rojas et al. 2009). The Marxist analyst Jeffery Webber, on the other hand, characterizes the Morales development model as disappointingly reformist, arguing that it reinforces existing class and capitalist structures through a neostructuralist development model 
that favors transnational corporations, the agricultural elite, and fiscal security over real structural change benefiting the poor (J. Webber 2011). In a more sympathetic analysis, Brent Kaup argues that the Morales government continues to be constrained in its options by the "path-dependent" effects of the neoliberal years, which set Bolivia on a development trajectory that is very difficult to change. Although it was able to renegotiate the rents from its natural gas resources, it was not able to change radically the material constraints of gas extraction, transport, and use, which keep it supplying gas benefiting Bolivia's neighbors' development projects more than its own (Kaup 2010).

In a scathing 2016 review of the first decade of MAS economic policy, the Bolivian economist Carlos Arze brings together all these critiques. He argues the government has followed a rent-seeking model that has returned the country to dependence on exporting primary materials. The nationalization, he asserts, was basically a reform of the tax regime with one central goal: to allow the government to capture profits from gas production for use for its populist projects, rather than to increase national economic growth. He shows that over the past decade, oil and gas exports have taken over a larger and larger percentage of the GNP, while agriculture and industry have fallen (2016: 6). Instead of producing goods for consumption, the country is importing more and more. As small-scale agriculture gives way to large agribusiness profiting a small elite, many campesinos are moving to the cities, where precarity and underemployment await them. The statistics on employment do not take into account the rise in vulnerable informal labor and the "pauperization" of the work force, he argues (11).

Moreover, despite the substantial changes to the economic system the MAS has enacted-restoring the state's role as a critical economic actor, redistributing resources to the poor, and so on-Bolivia remains deeply embedded in and vulnerable to global market forces. Its fortunes depend on global prices for its exports, and inasmuch as its reliance on gas-sector imports have increased over the decade of MAS administration, this dependency has only become greater. This makes the country's economic picture much less stable and has important implications for any claim to national sovereignty. Arze documents how the government has increased incentives for transnational companies working in Bolivia, allowing them to recover many costs. As a result, the transnationals have tripled their profits since 2005 (15).

Arze concludes that there is no sign of the indigenous alternatives promised by García Linera; instead, as market capitalism continues to be dominant and the state continues to capture rents from extractivism, communal forms of economy are reduced and the country becomes ever more dependent on monopoly capitalism. (27; see also Solón 2016). Eduardo Gudynas, a researcher at the Latin American Center for Social Ecology in Uruguay, has called this "progressive neoextractivism," which he defines as an emerging national development model of 
progressive governments like Morales's based upon the exploitation of natural resources and the export of primary materials. Gudynas contends that this differs a little from the traditional extractivist model because "the state plays a more active role, and gives extractivism a greater legitimacy because it redistributes some of the surplus to the population." Nevertheless, "it still repeats the negative environmental and social impacts of the old extractivism" (Gudynas 2010: 1; see also Bebbington 2010). Far from repudiating the dependence on international companies and markets, as that first emancipatory PND claimed a plurinational Bolivia would do, these progressive leaders maintain this dependence, replacing the negative connotations of exports and world markets with a new discourse about globalization and competition (4). Disappointed indigenous intellectuals point out that this return to Western notions of capitalism endangers the planet. Rafael Quispe, leader of the highland organization CONAMAQ, observes: "Capitalism or socialism is extractive, consumerist, developmentalist. In this sense they are the same. We have to speak of a new model of development, an alternative to this system. Because both capitalism and socialism will go on changing the planet" (quoted in Weinberg 2010).

Let us turn, then, to the environmental effects of the development model.

\section{THE LEGACIES OF EXTRACTIVISM IN BOLIVIA}

It is important to note that, long before the MAS came to power, Bolivia had a less than enviable record in terms of environmental protection (see Hindery 2013 for a detailed analysis of this record). For instance, in 1996, a tailings dam broke near the mining center of Potosí, flooding the Pilcomayo River with toxic materials. Because the mine was owned by Bolivia's president at the time, Gonzalo Sánchez de Lozada, the government did not insist on remediation (Farthing 2009: 27). Environmentalists and local activists are still pushing for remedies, and to close down the many ore-processing plants in the region. In 2000, a pipeline broke near a shallow part of Lake Titicaca, spilling thousands of gallons of oil into the Desaguadero River, contaminating 2,400 square miles of crop and grazing lands belonging to local indigenous people (Farthing 2009: 26; Haglund 2008). Again, little has been done to assist the victims.

These brief descriptions demonstrate what scholars and activists have been saying for years: Bolivia's historical legacy of extractive damage is ongoing, and it continues to create terrible environmental costs, much of which is borne by indigenous peoples at the local level (see Bebbington and Bury 2013). Environmentalists and local people fear that the development model put forward by the Morales government will continue this trajectory. The issue that received the most coverage at the 2010 Cochabamba Summit was the San Cristóbal mine, in the Nor Lípez province of Potosí department, near the famous Salar de Uyuni salt flats. The 
Japanese Sumitomo corporation had operated the massive open pit mine since 2008, when it took it over from Apex Silver, extracting silver, lead, and zinc. Over the weeks leading up to the Cochabamba Summit, the Regional Federation of Peasant Workers of the Southern Altiplano (FRUCTAS) led community members and workers in protest, blockading the roads and taking over the offices (López Pardo 2010). FRUCTAS representatives said the mine uses 15,000 cubic meters of water a day-that is, 600 liters every second-from the aquifer below the mine without paying for it. The result, they said, is that local streams have dried up, the rivers are polluted with toxic refuse, and agriculture has been ruined (Democracy Now 2010a). They demanded that the mine replenish the massive amounts of water it is currently using in its extraction processes, and that the usage be subject to taxes. For its part, the mine claimed it had lived up to its obligations under the 1997 mining law, and that it had paid about $\$ 350$ million dollars in taxes over the past ten years, although nothing for water (Carvajal 2010). The community members also wanted the mine to fulfill the promises it made when it began operations, such as electrification and improved roads (López Pardo 2010). Although FRUCTAS had made unsuccessful demands for years, the 2010 blockades finally got the government's attention. David Choquehuanca, Bolivia's foreign minister, blasted Sumitomo, calling it a "transnational that steals our natural resources, plundering tons of minerals every day but does not pay" for the water (Agence France-Presse 2010). The San Cristóbal mine, however, is only one of many toxic mines across the country. In 2010, the genetics department at the Universidad Mayor de San Andrés in La Paz reported that its tests at the San José Mine in Oruro had revealed genetic damage to residents who had inhaled the "contaminated" air near the mine. Scientists reported that 35 percent of mothers and 38 percent of children that they examined had alterations to their DNA as a result (Asociación de Teledifusoras de Bolivia 2010). The lack of government monitoring gives scientists and activists reason to fear that toxic wastes are creating a legacy of health problems, including increased risk of cancer, that will trouble Bolivia for generations to come.

Morales's government gave a huge concession to the Indian company Jindal to mine iron ore at the Mutún site near Puerto Suárez in the eastern Amazon area, near Bolivia's border with Brazil. Activists worried about the toxic by-products that seem likely to result from what would be the largest iron ore mine in South America. In recent years, disputes over the terms of the concession tabled the plan, but it might be revived again at any time. This draws attention to the question looming over many Latin American countries: overseas investments from the new Asian economies, especially China. While many have lauded the large amounts of money China has invested across the region, especially in petroleum, mineral extraction, and large-scale agriculture, scholars have noted the dangers that accompany this boom. Rebecca Ray and her colleagues note that Chinese investments are concentrated in sectors already vulnerable to environmental degradation and 
social conflicts about rights and working conditions. Few Latin American countries have been able to mitigate the social and environmental costs of trade and investment with China, they say (Ray et al. 2015: 2). In Bolivia, China has become an important trading partner, signing over four hundred cooperation, aid, and loan agreements. It is active in the mining sector and plans to become even more involved in exploiting Bolivia's lithium. China also exports large amounts of manufactured capital and consumer goods to Bolivia. Alejandra Saravia López and Adam Rua Quiroga report that despite high mineral exports, Bolivia has experienced a significant trade deficit with China (2015: 1). In their examination of China's Jungie Tin Mine, they conclude that the mine has caused significant clashes with local communities over water use and pollution. While the mining company has engaged in a productive community consultation process that appears to have resolved some of the social conflicts, the authors continue to be concerned about the lack of government environmental oversight and especially the new Law of Mining and Metallurgy, which gives mining priority use of water.

Mining has many additional associated environmental costs. For example, although the Jindal mine has not yet been opened, there are already huge damages from the highway that would support the mine. It is part of the new Bio-Oceanic Highway planned as part of the South American Regional Infrastructure Initiative (IIRSA; see de Alcantara 2013). The portion of that road already under construction from Santa Cruz to Puerto Suárez crosses through the department of Santa Cruz, across the dry forest lands of the Chiquitano people. The Organización Indígena Chiquitana (OICH; Indigenous Chiquitano Organization) has been protesting this road since its inception in 2000 and has documented serious damage to the fragile ecosystems along the road's trajectory, including deforestation, contamination of water sources, land conflicts, and loss of flora and fauna. OICH has also decried the lack of consultation with their authorities, bad working conditions, and the increase in social problems, including prostitution (Bailaba 2004; Erbol 2010a, b; Hindery 2013).

Bolivia's main source of income comes from the exploitation of hydrocarbons, mainly in the form of natural gas. But what are the effects of oil and gas development on local people? Most of the oil and gas wells-about 350 wells-are located in the Chaco area, in the dry lowlands in the southeast. Eighty-three percent of the reserves lie under the lands of the Guaraní people, who through the land reforms of the 1990 s were able to get collective title to small areas of their traditional territories, called territorios comunitarios de origen (TCOS). Geographer Penelope Anthias has documented the struggles of one TCO, the Itika Guasu TCO, where the largest gas field, Margarita, is located. Margarita is operated by a consortium of transnational oil companies, headed by Repsol and Maxus. Anthias documents the dismissive approach the companies took as they planned and carried out the exploration and development of the wells, ignoring Guaraní protests and demands, 
and polluting the lands of the communities in the process of drilling and extraction (Anthias, forthcoming). Years of protest by the people and the Asamblea del Pueblo Guaraní (APG) have produced little change, although a 2004 blockade and takeover of the well forced the government to establish a fund by which 2 percent of gas rents paid to the state would be reserved for development projects in Guaraní communities (Perreault 2008:12). Similarly, the geographer Derrick Hindery has detailed the effects that a natural gas pipeline through the Chiquitania Dry Forest has had on the Chiquitanos' lands. He argues that one should not analyze the effects of specific projects alone, like the pipeline, but instead should consider the "synergistic effects" of the whole "extractive complex" of development, including the secondary developments that come into the region along with the pipeline, like roads, which bring loggers, smugglers, and narco-traffickers, and additional projects like gold mines, with their own environmental risks (2013: 209).

The legacies of this form of extraction are well known in Bolivia, especially because indigenous peoples have been actively protesting against them for decades. That is why it is difficult for many indigenous people to understand why, despite the strong terms of both the PDN and García Linera's Andean Amazonian plan, the Morales government is aggressively pursuing several new megaprojects that have the potential for devastating impacts. First are the giant new lithium fields in the vast salt flat in southwestern Bolivia, the Salar de Uyuni. Because ultra-light lithium batteries will power cell phones and hybrid and electric cars in the new "green" future, there is a huge and growing demand for lithium. It could challenge petroleum as the dominant fuel of the future (Wright 2010). The good news for Bolivia is that the newly discovered fields contain about half the world's known lithium-an estimated 5.4 million tons-prompting many to predict that Bolivia will become the "Saudi Arabia of lithium" (Howard 2009; Romero 2009; Wright 2010). This effort is under way: a Chinese-funded plant making ion lithium batteries was inaugurated in 2014, and in 2015, Bolivia signed contracts with the German company K-UTEC AG Salt Technologies to design a lithium carbonate pilot plant and Chinese CAMC Engineering to build a potassium salt industrial plant (Sagárnaga López 2015). Scholars have serious doubts about the lithium development plan, pointing out that the government's figures do not seem to show the project is meeting its widely advertised promise (Guzmán 2014: 6).

Scholars and activists have expressed deep concerns about the environmental dangers the project may bring. They argue that like any other non-renewable resource, producing lithium will take its toll on the fragile ecosystem of the Salar de Uyuni, and the Rio Grande delta, where flamingos breed. To exploit the lithium, Bolivia will create large brine beds and evaporation ponds, and then re-inject the leftover salt, increasing salinity of the rivers, which local people use to irrigate their farms. The simplest way of processing lithium involves mixing magnesium with the lithium, producing toxic magnesium hydroxide (Meridian 2008; Tegel 2013). 
Activists and community members are worried about contamination if this method is chosen, as well as the big question of where the water will come from for all this (Tegel 2013). The Bolivian anthropologist Ricardo Calla has investigated the various options, and fears the government has chosen the most dangerous form of extraction (R. Calla Ortega 2014). Because the government is not entirely transparent about the project, however, it is difficult to make conclusive evaluations. Environmentalists are also concerned about the dangers of highly corrosive lithium hydroxide, produced when lithium combines with water. During the rainy season, the salar often floods - which is why the birds come to breed there. The Foro Boliviano sobre Medio Ambiente y Desarrollo (FOBOMADE; Bolivian Environmental Defense League) warns that the government has not carried out sufficient water or environmental studies yet, so it is difficult to project what the long-term effect might be (Howard 2009; see also R. Calla Ortega 2014). The Salar de Uyuni is now the most visited ecotourist attraction in Bolivia, and many fear the lithium production will harm this critical resource and source of income (Aguilar-Fernández 2009).

What will this project mean for local populations? There is no clear answer yet, because the project is in its initial stages, but investigators are already seeing significant effects. The local indigenous people have traditionally made their living mainly by growing quinoa and raising camelid livestock. The local communities are spread out across the region, and organized in cultural-political entities called ayllus, as well as in originary communities and peasant unions, or sindicatos (R. Calla Ortega 2014). Agriculture still represents 65-85 percent of their income, but they have increasingly turned to ecotourism, construction, seasonal migration, salt farming, and craftwork to supplement their incomes. Rodrigo AguilarFernández suggests that using the limited water resources for lithium processing will make it impossible for local communities to continue farming quinoa, despite its high yield and steady market prices (2009). Calla argues that the project has already produced enormous cultural and political change, inasmuch as the Federación Regional Única de Trabajadores Campesinos del Altiplano Sur (FRUTCAS; Regional Federation of Peasant Workers of the_Southern Altiplano), has negotiated with the state over the years to title peasants' lands under the territorial titling act, or INRA. To ensure that it would have control over the lithium resources, the state cut a deal, giving collective title to three enormous TCOS to local peasant communities. In exchange, the Salar de Uyuni remains under the control of the central state. Calla argues this was an enormous loss for the local indigenous people, who "lost in favor of the state all property rights over the salar... Thus, an ancient and proud centuries-old perception held by the old ayllus and rural communities that the Salar of Uyuni had been and would be theirs was juridically cut off, perhaps forever" (R. Calla Ortega 2014: 51). He suggests that they remain vulnerable to environmental damage, especially if the soils become salinated. An 
ecological disaster like that, he says, would lead to the disappearance of the cultures of the rural indigenous peoples, who would have to abandon their pastoral livelihoods and emigrate to the cities, increasing a trend already under way (53). Some local community members are expressing their fears that the water levels are already going down, harming the animals, and "killing our Mother" (see interviews in Martín-Cabrera and Ramírez Pimenta 2016). Calla notes that for the most part, local communities do not know what the project will bring and are waiting to see what will happen and what benefits might come.

Yet many other national, regional, and local actors-including some who identify as indigenous-continue to push for lithium despite these dangers. The government has made it clear that this is a high priority, and has promised to make this a new sort of extraction, where, instead of only providing raw materials to foreign companies, Bolivia would benefit equally with its international partners by producing value-added products. Regional governments in Potosí are supportive because they want the state to channel profits from lithium back to the region, one of Bolivia's poorest departments. The large mining sector in the region means there are already many people, including indigenous residents, who work as miners and see the lithium project as a potentially lucrative source of employment. Many in the tourism industry see the lithium industry as a way to attract important infrastructure, like airports and an asphalted highway (Ströbele-Gregor 2010). These desires for work and infrastructure explain, in part, why the local peasant organization, FRUTCAS, which represents many indigenous farmers, has been one of the strongest supporters of the state's initiative, and especially its anti-imperialist stance towards developing it. FRUTCAS is strongly MASista, and has benefited enormously from MAS's continued support-especially territorial recognition. FRUTCAS argues that the lithium project is part of a sustainable use of natural resources that will benefit all. "This project is ours, because we are the guardians and monitors of good development of this strategic project, for the region, the department, and the country," FRUTCAS's leader declared (cited in Ströbele-Gregor 2012: 62). Here indigeneity is equated with sovereignty over natural resources, and not opposed to extractivism or development.

The second mega-project looming on the horizon is the Cachuela Esperanza dam planned as part of the IIRSA (Initiative for the Integration of the Regional Infrastructure of South America) initiative in the Beni region of the Bolivian Amazon. This dam is part of the Madeira River Hydroelectric Complex, the largest hydroelectric project in the Amazon. The project will dam the second largest river of the Amazon basin, inferior only to the Amazon River itself. The Madeira River carries half of the sediments of the entire basin and feeds one of the most biologically diverse regions of the world, which is shared by three countries: Bolivia, Brazil, and Peru. The Complex involves the construction of four hydroelectric plants: two in Rondônia, Brazil, near the border with Bolivia, are under construction; a third one, 


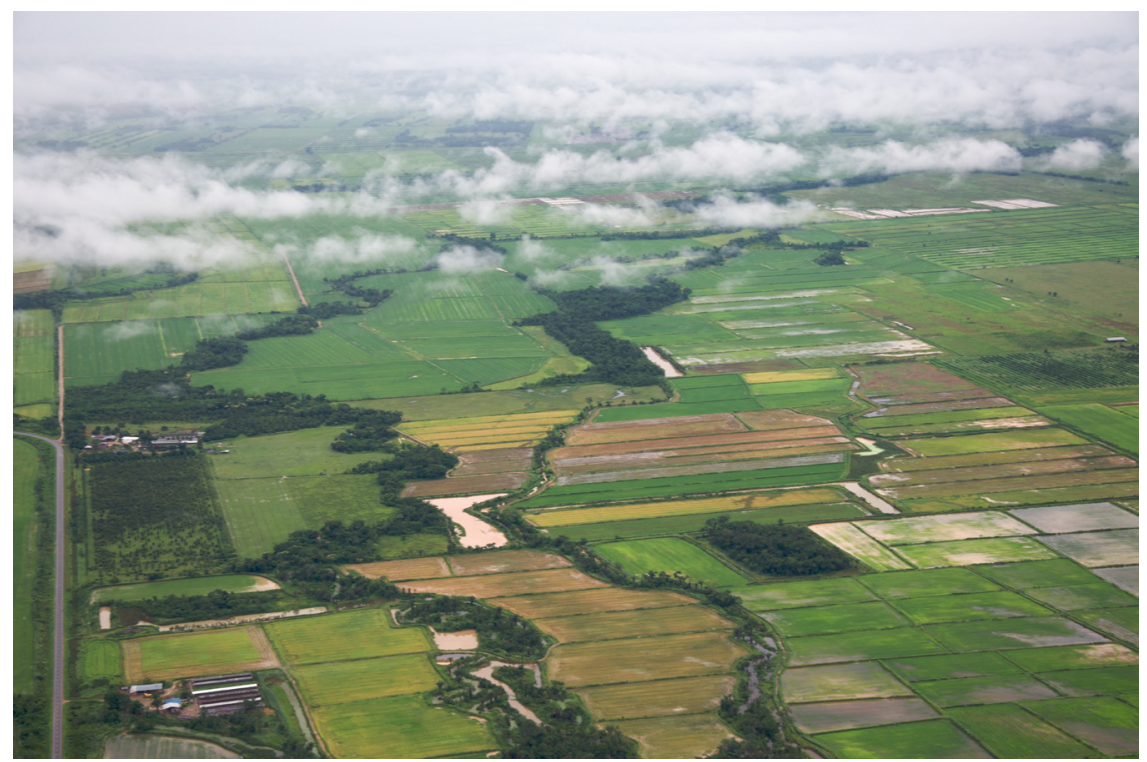

FIGURE 8. The advancing agricultural frontier in Santa Cruz. Credit: Sam Beebbe. https:// creativecommons.org/licenses/by-sa/3.o.

Cachuela Esperanza located in northern Bolivia, is in advanced stage of studies; and the fourth one, Guayará-Mirin located in bi-national (Brazilian-Bolivian) waters, is still in initial studies (Bank Information Center 2010). Indigenous peoples all along the river's trajectory have protested the dams, which will inundate millions of acres of lands and forests, destroying wildlife and ecosystems. A particular concern is the fish population, one of the most diverse on the planet. Critics claim that the dams will disturb mercury deposits - refuse from mining over the yearswhich will be ingested by the fish, and then by the river-dwelling populations who subsist on those fish (Denvir and Riofrancos 2008). Despite these concerns, the MAS government is proceeding, and in March 2016, it signed a memorandum of understanding with Brazil to spur viability, design, and construction studies for both the Rio Madera and Cachuela Esperanza dams. The goal is to expand hydroelectric power generation (Fox News Latino 2016). This project is still in the planning stages, so there is little reported about how local people are responding.

Finally, we cannot understand Bolivia's economic and environmental situation without calling attention to the growing importance of capital-intensive mechanized agribusiness model in the lowlands. As Nicole Fabricant and I have described in our 2014 analysis of the long-term patterns of agriculture in lowland Bolivia, indigenous labor and lands have long been incorporated into large-scale 
commodity production, from rubber to sugar to the current dominant product, soy. Since the 1940 s Bohan Plan, the government has organized large-scale colonization of the lowlands as a way to bring poor farmers from the dry highlands to the fertile lowlands. They cleared an enormous amount of land in the first period. But over the past two decades, expanding soy plantations have altered the agrarian structure and led to major environmental changes. Ben McKay and Gonzalo Colque describe the development of what they call the mechanization, concentration, and expansion of the "soy complex." They argue that in the 1980s and 1990s, with the advent of foreign producers and capital, and the introduction of new technologies, labor power became less necessary and industrial crops began to be exported. Much of Bolivia's fertile land is now owned by foreigners-especially Brazilians, Croatians, and Japanese-and Mennonites (McKay and Colque 2015; Urioste 2011). Global demands for soy product, especially from China and Europe, have exacerbated this process, and the use of industrial fertilizers, genetically modified seeds, and the large amount of capital needed now make this level of production very difficult for small-scale farmers (McKay and Colque 2015: 2). The result, they say is a process of "productive exclusion" marked by the proletarianization of the rural work force and a concentration of capital and land into a small elite of agribusiness interests. Scholars have described the massive deforestation that this agribusiness system produces, ascribing to mechanization the largest cause of loss of forested areas (Mueller et al. 2012; INESAD 2013).

Originally, Morales and the MAS government threatened the agribusiness sectors, calling for massive land reform. Concerns about this new form of latifundio as well as its environmental effects were an important source of debate at the Constituent Assembly, where delegates voted to limit the number of hectares anyone could control. The Bolivian public voted in a special referendum about the exact number, agreeing to five thousand hectares, which is now mandated by Article 38 of the Constitution. Yet the government negotiated with the agro-industrial groups to incorporate an additional provision allowing an unlimited number of business associates to hold up to five thousand hectares apiece (Bolivia 2009: Art. 315, pt. 2), "rendering the land ceiling futile" (15). In recent years, Morales has essentially cut a deal with this sector, allowing it to export without any trade restrictions, and supporting it with infrastructure. The new development plan for the next decade, Agenda Patriotica 2025, calls for an expanded agricultural frontier in order to increase the country's ability to feed itself. Such calls are cause for grave concern to indigenous and environmental organizations.

\section{THE TENSIONS IN THE NEW EXTRACTIVISM}

How do we make sense of the dissonance between Morales's words about protecting Mother Earth and these images from Bolivia of the environment and indigenous 
communities under attack? First, as pointed out above, it is unfair to blame Morales for Bolivia's long history of natural resource development. Bolivia has exported primary materials since the Spaniards began mining gold and silver, through the long years of tin mining, to the recent years of natural gas extraction. "Bolivia's history and environment have been dominated by relentless extraction" (Farthing 2009: 25). In essence, Morales took on a country that was already "primary resourcedependent," and to alter that model will take time and effort (Denvir and Riofran$\cos 2008$ ). Bolivia does not exist in a vacuum, but is and has long been enmeshed in a global economic system that exerts its own force and momentum.

Second, the Morales government has taken a leading role in pushing international institutions to rethink their approaches to global climate change. Influenced in part by civil society organizations like the Plataforma Boliviana Frente al Cambio Climático (Bolivian Platform against Climate Change), which brings together indigenous and other popular sector demands, the Morales government has urged developed countries to slash their emissions farther than they have pledged to do. Morales gave fiery speeches at the Copenhagen Summit in 2009, and Bolivia refused to sign onto the negotiated accord, drawing the ire of the United States (Schipani and Vidal 2014). In Copenhagen and beyond, Morales and his UN representative, Pablo Solón, relentlessly pushed back against the idea of a market-based model of carbon offsets, arguing that such a model does not resolve the underlying causes of deforestation and degradation of forests. They have been key players in the debates over programs like Reducing Emissions from Deforestation and Forest Degradation (REDD and REDD+) in which industrialized countries would purchase offsets and establish funds to pay developing countries to maintain forests. Morales and Solón have argued that these "false solutions" only reinforce the capitalist production responsible for climate change in the first place, while attempting to drag developing countries like Bolivia further into the logic of the market. At the Doha Climate Convention in 2012, Bolivia's Minister of the Environment and Water, José Antonio Zamora Gutiérrez, followed suit, arguing that the "climate is not for sale," and declaring that the withdrawal of developed countries from the Kyoto Accord was an attack on Mother Earth (cited in Hicks and Fabricant 2016: 17). Kathryn Hicks and Nicole Fabricant trace the influences the Plataforma Boliviana had on the Morales government in the first administration, showing how they used discourses of the "ecological Indian" strategically to problematize normative models of development and push for more sustainable models (ibid.). The alternative Cochabamba Summit, with which this chapter opens, was another key site where indigeneity was the frame for critique and organizing.

Nevertheless, the Morales government argues it must continue to extract natural resources in order to provide for the welfare of the poorest and most marginalized people of Bolivia. Defending a government plan to build a highway through a 
tropical park and indigenous territory (discussed in the next chapter), Vice President Álvaro García Linera made clear the government's priorities:

We are going to construct highways, we will drill wells, we will industrialize our country, preserving our resources in consultation with the people, but we need resources to generate development, for education, transportation, and the health of our people. We are not going to turn ourselves into park rangers for the powers of the North who live happily, while we continue in poverty. (Erbol 2010c; my translation)

One can read the vice president's statement as a demonstration of the tensions inherent in the model between the indigenous value of buen vivir and the search for alternatives to capitalism, on the one hand, and the desire for and the need to redistribute the profits from natural resource extraction to the Bolivian people, on the other. But even this difficult duality is not so clear. As the preceding chapters have made clear, what is "indigenous" is not a given; rather it is a site of politics, in which different parties claim indigeneity as either a way to contest the existing order, or a site of policing from which to consolidate new orders. Vivir bien is also a discursive artifact, useful for the state to push its views at the international level, and useful for activists at the Constituent Assembly to push for the alternative sorts of development they envisioned. What becomes visible from understanding indigeneity as a site of politics and policing is that the changing political economy has altered the meanings and potential of all these ideas and terms.

In the first MAS administration, vivir bien was shorthand for challenging the neoliberal development projects of past eras, making indigeneity into a vehicle of change and a window onto a horizon of possibility. But, as the government continued its extractivist development model, these alternatives faded in importance in the public sphere, and indigeneity and buen vivir became linked to state projects like lithium extraction. The call for a just distribution of Bolivia's natural patrimony was an essential part of the water and gas wars that brought Morales to power in the first place and led to his reelection in 2010. As the poster in figure 9 makes clear, the sense that Bolivia was moving forward, "advancing" was important. Note that this was not just a call to keep the profits at home, but also a call to industrialize at home. The majority of Bolivians, and that includes many indigenous people, are proud of the nationalization, and delighted that Morales and his associates reversed the unfair terms of the gas business. They want lithium to be developed, and they want their standards of living to improve. This is part of pachakuti, the turning of the timetable, the change of destiny. This is the time for the formerly poor to receive their fair share. A large number of indigenous Bolivians live in cities, surviving in difficult economic situations. For them, the most important goal of the new decolonized state is to pass the benefits of national patrimony to the poor who were traditionally barred from those benefits. They are not as concerned about environmental damage to rural lands as they are about overcoming poverty. 


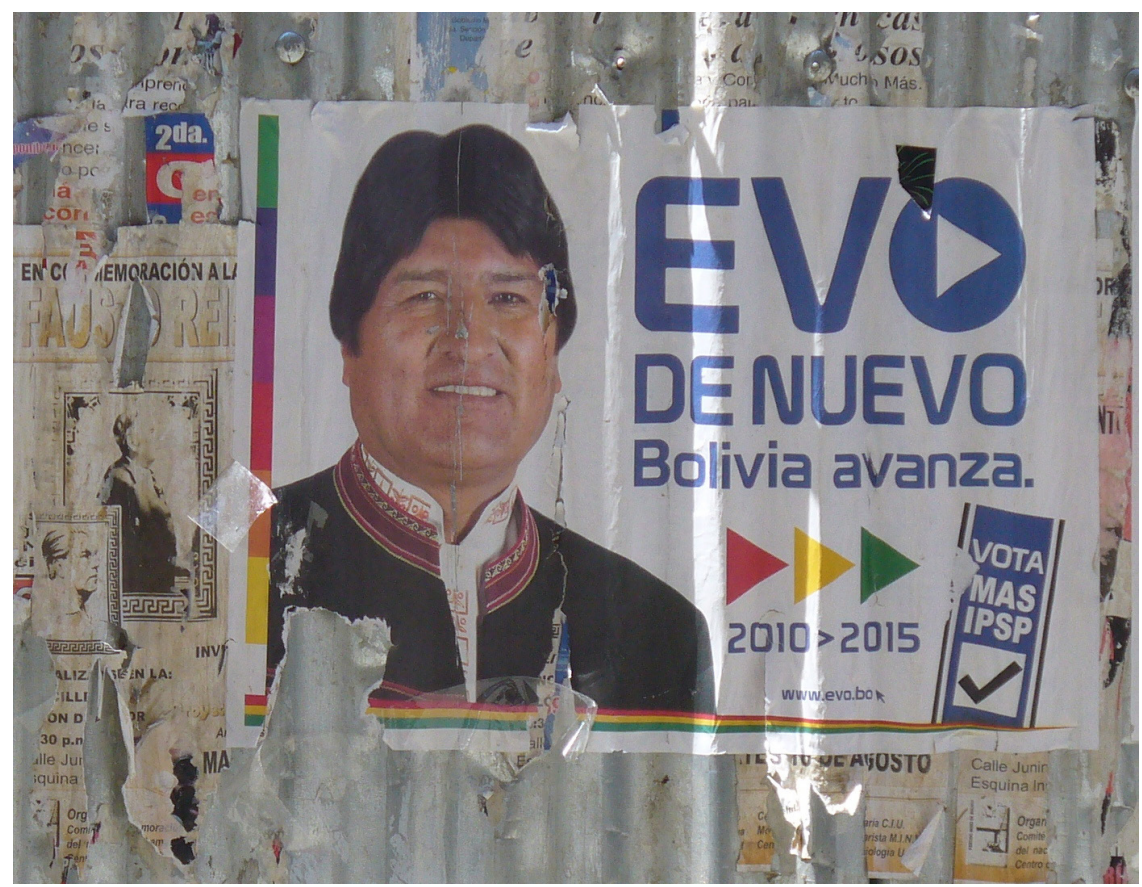

FIGURE 9. 2010 election campaign poster for Morales. It reads: "Evo, again. Bolivia advances." Credit: jmage. https://creativecommons.org/licenses/by-sa/3.o/

As Nicole Fabricant points out, for urban people, gaining access to water and jobs may be more important than any abstract notion of Pachamama or even climate change (Fabricant 2013). Bret Gustafson concludes that "gas in Bolivia is not primarily understood through the lens of climate change-though climate change and its effects and causes are clearly part of Bolivian political consciousness-but as a medium for negotiating rights, well-being, and exchange between citizens and the state" (Gustafson 2013: 64). He points to the public spectacles that have become common in recent years, as the president inaugurates new natural gas lines into domestic homes in El Alto and La Paz with great pomp and much publicity. Sweeping aside the environmental costs to those whose lands were sacrificed to provide this gas to urban residents, Morales tells the public that "Thanks to Mother Earth," Bolivia has "cheap gas" (ibid.). For many, this was a welcome message.

Oscar Olivera, the leader of the protesters in the 2000 water war in Cochabamba, suggests that this tension existed even before the Constituent Assembly. Emerging from the water and gas wars in 2000 and 2003, and then a referendum on gas exploitation in 2004, and eventually the nationalization of gas in 2006, he told me, most people felt that "a process of transformation, of substantial change 


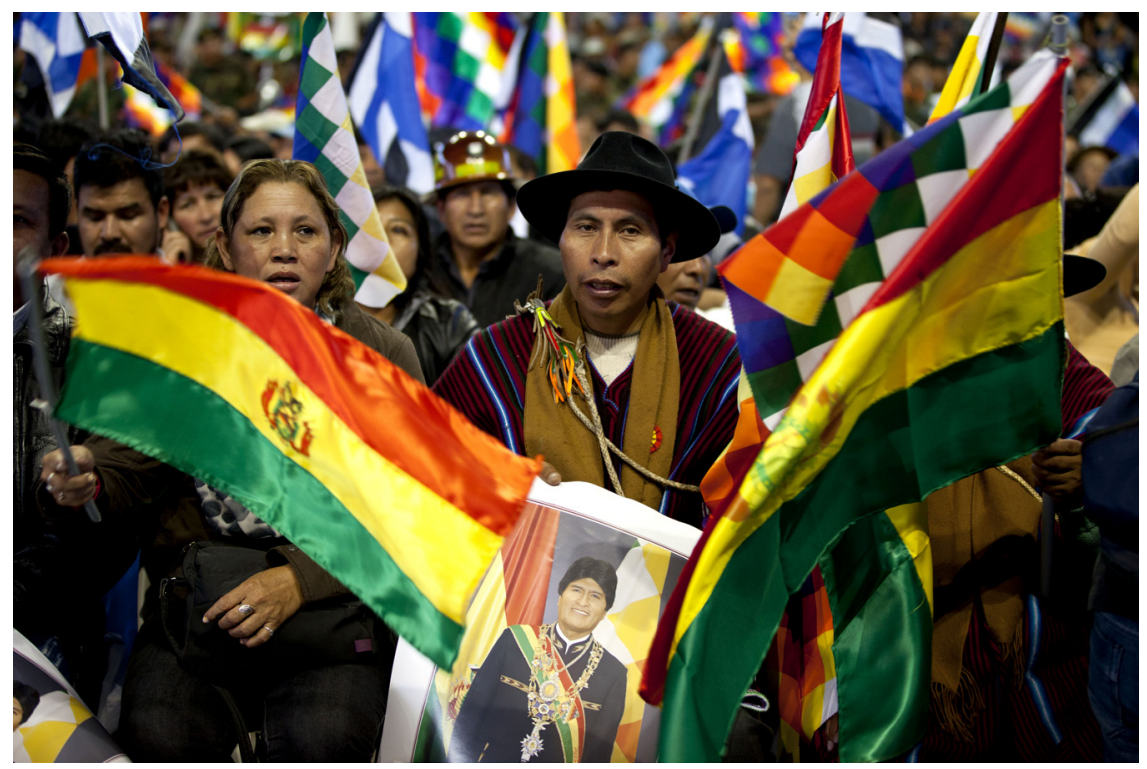

FIGURE 10. Morales supporters at 2013 rally in Cochabamba. Credit: Fernanda LeMarieCancillería de Ecuador. https://creativecommons.org/licenses/by-sa/3.o.

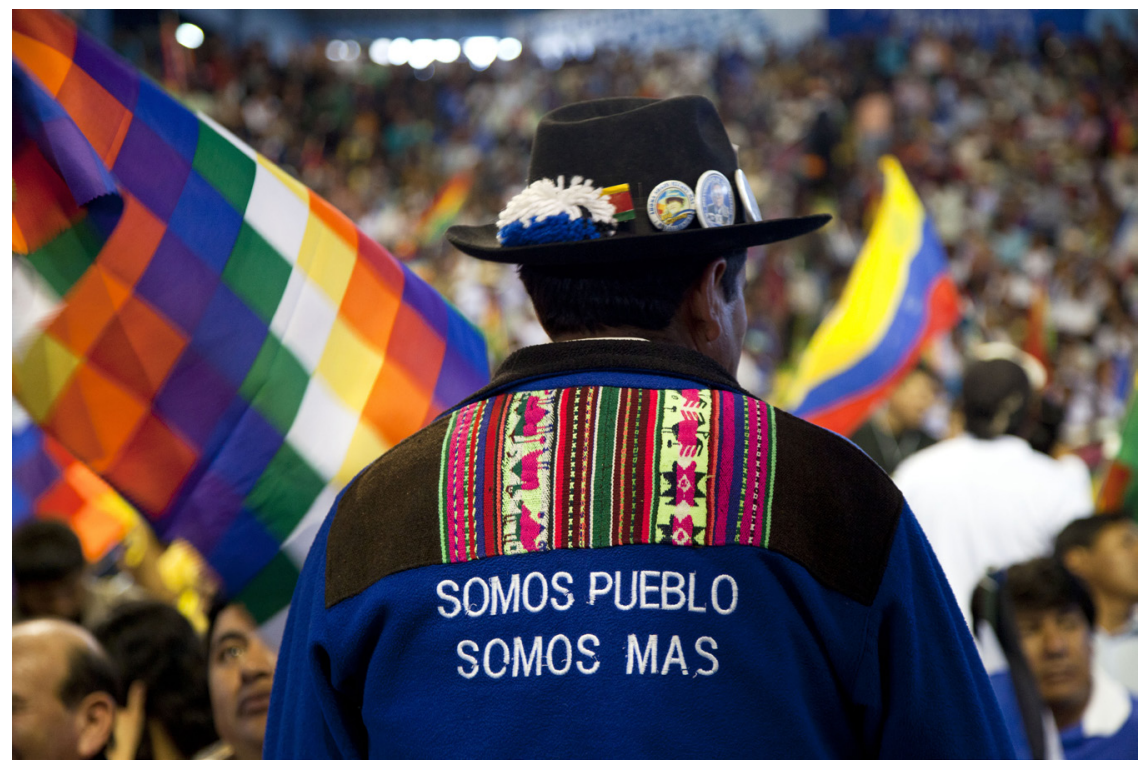

FIGURE 11. Morales supporter at 2013 rally in Cochabamba. The slogan on his coat translates as: "We are the People/We are MAS/We are more." Credit: Fernanda LeMarie-Cancillería de Ecuador. https://creativecommons.org/licenses/by-sa/3.o. 
had to pass through a stage of re-appropriation of our natural resources." But this did not have to be accomplished through a "purely state-run process." Instead, the idea was "the social reappropriation of the inherited patrimony of our parents, of our grandparents: the natural resources and public enterprises that had been privatized" (personal communication, August 2012). The question, of course, is how can this "social reappropriation" work in a state dedicated to continued engagement with state-controlled global capitalism?

These tensions have not eased; rather, they have become even more intense. What has changed is the government's discourse, which now links natural resource extraction to decolonization. Part of this is because the original makeup of the government, as described in chapter 1 , has evolved. The indigenista proponents of vivir bien have mostly left the government. For example, Raúl Prada, one of the architects of the Pacto Unidad's constitutional proposals, served as minister of development and planning in the first Morales administration. He used that position to push for sustainable development alternatives based on indigenous customs, but left the government as it became obvious how little priority the government was giving these options. Now he is now firmly in the dissenters' camp, writing eloquent critiques of the extractivist program of the government (see, e.g., Prada Alcoreza, 2012, 2013). At the same time, the vice president's push to industrialize has gained strength, and his vision of development has taken new legal form. This culminated in October 2012 when the congress approved the Ley Marco de Madre Tierra y Desarrollo Integral para Vivir Bien (the Framing Law of Mother Earth and Integral Development to Live Well), which brings the language of vivir bien and the goal of integral development together.

While one can read this new law as a commitment to protection of the environment, a close reading makes clear that the law subsumes the "horizon" of vivir bien to the state-led process of "integral development." This term is not defined, but the law's terms make clear that it is a balancing act, in which capitalism and decolonization must be held in productive tension-similar to the tensions within the 1990 s term "sustainable development." Vivir bien is described as a "new cultural and civilizational horizon" which operates as "an alternative to capitalism and modernity" and arises from the cosmovisión of indigenous originary peasant peoples and nations (Ley Marco, Art. 5, no. 2). So, vivir bien is still the goal at which the plurinational state aims, but the mechanism by which it will accomplish this has changed. Under the new law, the means by which this horizon is to be reached is integral development, which is understood "within the framework of decolonization" (Art. 8). The text explains that the move towards vivir bien can only be implemented understanding the complementarity between four sets of rights:

(a) the rights of Mother Earth, as a collective subject of public interest;

(b) the individual and collective rights of indigenous, originary, peasant, 
intercultural, and Afro-Bolivians;

(c) the fundamental civil, social, economic, and cultural rights of the Bolivian people to live well through integral development; and

(d) the right of the urban and rural populations to live in a society of justice, fairness, and solidarity without material social, or spiritual poverty ... (Art. 4, no. 1)

The political economist Eduardo Gudynas argues this new formulation is extremely significant. He says "it restores the idea of development, legitimating it in a political norm and placing it as a necessary element for vivir bien. . . This turnabout should not be understated, because it minimizes vivir bien and robs it of its vocation as a radical break with development and the transcendence of modernity. Not only this, but now, a certain type of development is necessary to achieve vivir bien" (Gudynas 2013: 25). For Guydnas, the new law is a sign that the Morales government has for all intents and purposes silenced those hoping for real alternatives to development. "This restoration of the idea of development closes a chapter in the Bolivian process," he says. "Now it is possible to promote extractivism and defend it as a necessary form of integral development without falling into contradictions" (ibid.).

In this chapter, I have traced the evolution of the relation between development and decolonization since Morales's election, arguing that after taking power, the government was forced to balance tensions between capitalist notions of industrialization and extraction against alternative visions of development based on indigenous customs and values. By 2012, despite its earlier rhetoric, the state appeared to have accepted the inevitability of capitalist models, and justified this as necessary to move the country and its peoples forward to decolonization, social justice, and living well. Moreover, it accomplished this in great part by using the discourses of indigeneity, transforming the site of politics into a kind of policing that is difficult to contest. As I show in the following chapters, the consolidation of the capitalist extraction model has had several important effects. In the next chapter, I consider the profound effects it has had on the question of race relations and on racism. I show how the Morales government has not only continued the development path but also reinscribes the racialized effects of it, sacrificing lowland indigenous lives and lands. In chapters 6 and 7, I describe how this new discourse increasingly requires local political actors to negotiate their identities and demands for citizenship in terms of economic development and class. 